\title{
Laudatio in honour of Professor Herbert Gleiter
}

$\mathrm{T}$ he October issue of the Zeitschrift für Metallkunde is dedicated to Professor Herbert Gleiter to mark his 65 th birthday in October 2003. The habit of thus honouring eminent German materials scientists is a pleasing feature of the Zeitschrift and also of the Deutsche Gesellschaft für Materialkunde which is closely linked to the journal, and I feel privileged to have the opportunity of doing this service for Herbert Gleiter. There can be no conceivable doubt that he occupies the highest level of distinction in his field: more than that, he is a member of that select subset of distinguished scientists whose name is indissolubly attached to a major technical innovation. I think of him as Doctor Nanocrystallinity.

Herbert Gleiter has been like a wandering bee who has alighted on many different flowers and has carried ideas effectively from one to the other, again and again. The analogy is imperfect, however; a bee relies on the plant to generate its own nectar, Gleiter more often than not manufactured the nectar himself. He spent fruitful time at the universities of Stuttgart, Bochum, Göttingen, Harvard, Saarland and Hamburg, also MIT in Massachusetts and the ETH in Zürich, before moving on later in his career to a senior position in one of Germany's national laboratories, in Karlsruhe, where he put the experience of half a scientific lifetime to effective use. That experience can best be summarised by describing him as an experimental microstructuralist (in German, this might perhaps be rendered as Gefügebefugter) who has systematically explored the internal structure of all kinds of materials at an everdiminishing scale, with a strong focus on the characteristics of grain boundaries. The experiments he conducted during his time at Harvard, searching for anomalies in the plot of grainboundary energy as a function of misorientation, by means of the so-called rotating crystallite method, have long seemed to me a model of scientific ingenuity, and they proved for the first time that for certain specific types of misorientation only, the normally highly disturbed local structure of a grain boundary becomes more orderly.

The well-founded conviction that grain boundary structure in most cases is highly disordered led him, in 1980, to the recognition that a polycrystal in which the grains are so small that the grain diameter is comparable with the thickness of the disturbed grain-boundary zones should have properties quite different from ordinary, coarse polycrystals. The next year, he set our his ideas and predictions in depth at an international scientific colloquium in Denmark and that initiated a stampede of research around the world devoted to 'nanocrystalline' or 'nanostructured' materials. He developed his ideas systematically, first in Saarbrücken
$\mathrm{D}$ as Oktoberheft der Zeitschrift für Metallkunde ist Professor Herbert Gleiter aus Anlass seines 65. Geburtstag im Oktober 2003 gewidmet. Die Tradition, dass herausragende deutsche Materialwissenschaftler in dieser Form gewürdigt werden, ist ein bemerkenswerter Vorzug dieser Zeitschrift und der Deutschen Gesellschaft für Materialkunde, die mit ihr eng verbunden ist, und ich fühle mich durch die Gelegenheit geehrt, diese Widmung für Herbert Gleiter zu verfassen. Es besteht kein Zweifel, dass seine herausragenden wissenschaftlichen Verdienste auf höchste Anerkennung in seinem eigenen Forschungsgebiet stoßen; zusätzlich gehört er sogar zu jenen wenigen Forscherpersönlichkeiten, deren Name untrennbar mit einer bedeutenden technologischen Innovation verbunden ist. Für mich ist er schlicht der doctor nanocristallorum.

Herbert Gleiter hat etwas von einer fleißigen Biene, die unermüdlich von einer wissenschaftlichen Blüte zur nächsten wandert und dabei jede einzelne mit neuen Ideen befruchtet. Diese Analogie greift zu kurz: während die Biene auf die Blüte angewiesen ist, um Nektar zu gewinnen, hat Herbert Gleiter oft genug wissenschaftlichen Nektar ohne fremde Hilfe hervorgebracht. Er verbrachte fruchtbare Perioden an den Universitäten in Stuttgart, Bochum, Göttingen, Harvard, Saarbrücken und Hamburg, darüber hinaus am MIT in Massachusetts und an der ETH in Zürich, bevor er in den Vorstand des Forschungszentrums Karlsruhe berufen wurde, um seine wissenschaftlichen Erfahrungen aus einer halben Lebensspanne für die Helmholtz-Gemeinschaft deutscher Forschungszentren nutzbringend einzusetzen. Wollte man diese Erfahrungen zusammenfassen, so würde man ihn vielleicht am besten als experimentellen Mikrostrukturphysiker beschreiben, der systematisch die innere Struktur aller möglicher Arten von Materialien erforscht hat, dabei zu immer kleineren Längenskalen vorgedrungen ist und dabei die Eigenschaften der Korngrenzen in den Mittelpunkt seiner Untersuchungen stellte. Die Experimente, die er in dieser Zeit an der Harvard University durchführte, um nach Anomalien in der Grenzflächenenergie in Abhängigkeit von der Fehlorientierung mit der sogenannten ,,rotating crystallite“-Methode zu suchen, empfinde ich seit langem als Modellbeispiel wissenschaftlichen Einfallsreichtums. Diese Untersuchungen zeigten zum ersten Mal, dass die normalerweise stark gestörte lokale Struktur einer Korngrenze für spezielle Orientierungsunterschiede sehr wohl eine gewisse Ordnung aufweisen kann.

Die wohlbegründete Überzeugung, dass sich die Korngrenzenstruktur im Allgemeinen durch eine hohe Unordnung auszeichnet, führte Herbert Gleiter 1980 zu der Schlussfolgerung, dass Polykristalle, in denen der Durch-
* In the second half of 2003 the Editorial Board of the Zeitschrift für Metallkunde was restructured. Regrettably, owing to this process of restructuring, the laudatio in honour of Prof. Dr. Herbert Gleiter was not printed in the October issue. We would like to apologize to the readers of the Zeitschrift für Metallkunde for this inconvenience.

\footnotetext{
* In der zweiten Hälfte dieses Jahres erfolgte eine Umstrukturierung des Herausgebergremiums unserer Zeitschrift für Metallkunde. Im Verlauf dieses, sich über einige Monate hinziehenden Prozesses wurde es leider versäumt, die hier abgedruckte Laudatio zu Ehren von Herrn Prof. Dr. Herbert Gleiter für das Oktoberheft zum Druck freizugeben. Dies soll an dieser Stelle nachgeholt werden. Wir möchten uns bei unseren Lesern für diese Unannehmlichkeit entschuldigen.
} 
and later in Karlsruhe. His own emphasis were on such aspects as mechanical properties as a function of grain diameter - that is, he focused his personal attention on loadbearing nanostructured materials; however, the worldwide effort that he unleashed also spread to functional materials of various types, and the nanostructured quantum dot, for example, became a familiar concept to materials scientists everywhere.

I owe Herbert Gleiter a personal debt of gratitude for his splendid, comprehensive chapter on 'Microstructure', written (and updated) for the later editions of the multiauthor text, Physical Metallurgy, edited by Cahn/Haasen, a chapter which I have read afresh on many occasions, always with scientific profit.

I wish Herbert Gleiter many healthy years to be devoted to the science that he loves so much and has graced with such exemplary achievement.

Robert Wolfgang Cahn, Cambridge, England messer der Kristallite vergleichbar ist mit der Dicke der ungeordneten Korngrenzen, deutlich andere Eigenschaften haben sollten als gewöhnliche grobkristalline Materialien. Im darauf folgenden Jahr stellte er diese Ideen und die daraus resultierenden Vorhersagen anlässlich eines internationalen wissenschaftlichen Kolloquiums in Dänemark vor, was zu einem weltweiten Ansturm der Forschung an ,nanokristallinen“ oder ,nanostrukturierten“ Materialien führte. Diese Konzepte entwickelte er systematisch weiter, zunächst in Saarbrücken, später in Karlsruhe. Einen persönlichen Schwerpunkt legte er dabei auf den Aspekt der korngrößenabhängigen mechanischen Eigenschaften; hier widmete er sich mit besonderem Interesse dem Verformungsverhalten nanostrukturierter Materialien. Zugleich begannen sich die durch ihn initiierten weltweiten Forschungsanstrengungen auch auf verschiedenste Arten von Funktionsmaterialien auszudehnen. So sind Materialforscher heute überall auf der Welt vertraut mit dem Konzept nanostrukturierter Quantenpunkte welche auch direkt auf diese frühen Ideen zurückgehen.

Persönlich schulde ich Herbert Gleiter Dank für sein wunderbares Übersichtskapitel zum Thema ,Microstructure“, das er für die letzten Ausgaben der Monografie „Physical Metallurgy“ (Herausgeber: Cahn/Haasen) geschrieben und dabei auf aktuellem Stand gehalten hat. Dieses Kapitel habe ich bei vielen Gelegenheiten immer wieder neu - und stets mit wissenschaftlichem Gewinn - gelesen.

Ich wünsche Herbert Gleiter noch viele Jahre guter Gesundheit, die er der Wissenschaft widmen möge, welche er so sehr liebt und die ihn dafür mit solch herausragenden Erkenntnissen belohnt hat.

Robert Wolfgang Cahn, Cambridge, England 